The lack of effects of phentolamine and oxymetazoline is not incompatible with this assumption. The catecholamine concentration in the vicinity of the chromaffin cells is very high. The amines may prevent access of the competitive antagonist phentolamine to the $\alpha$-receptors, and maximal activation of the feed-back inhibition by catecholamines may prevent any additional inhibitory effect of oxymetazoline. Only the irreversible antagonist phenoxybenzamine effectively blocks the receptors and disinhibits secretion.

Zusammenfassung. Der Einfluss von Desipramin, Oxymetazolin, Phentolamin und Phenoxybenzamin auf die durch $40 \mathrm{~m} M$ Kalium hervorgerufene Abgabe von Katecholaminen aus isoliert perfundierten Rindernebennieren wurde untersucht. Desipramin, Oxymetazolin und Phentolamin bewirkten keine Änderung; $10^{-5} M$ Phenoxy- benzamin erhöhte die Freisetzung. Dies deutet auf eine durch $\alpha$-Adrenoceptoren vermittelte Rückkopplungshemmung der Freisetzung von Katecholaminen, ähnlich der an noradrenergen Nerven.

\section{K. Starke, B.-D. Görtitz, H. Montei} and H. J. ScHÜMANN 17

Pharmakologisches Institut, Universitäts-Klinikum Essen, Hufelandstrasse 55,

D-4300 Essen (Federal Republic of Germany), 18 June 1974.

17 We are grateful to Miss E. M. Betzinger and Miss I. MülLer for skilful technical assistance. This work was supported by the Deutsche Forschungsgemeinschaft.

\title{
Influence of 2-Br- $\alpha$-Ergokryptine-Mesilate (CB 154) on the Pituitary Prolactin Content of Prooestrus Rats
}

In cycling female rats, an increased release of $\mathrm{LH}$ (ovulatory surge) from the pituitary occurs during the afternoon of the prooestrus phase. This is accompanied by a similar surge of prolactin. In the late afternoon of prooestrus, the pituitary contains much less prolactin than in the morning ${ }^{1}$, while the serum prolactin shows several times higher levels in the afternoon than in the morning ${ }^{2}$. We have used the prooestrus rat to test CB 154 for its inhibitory action on a spontaneously occurring pituitary prolactin depletion.

Methods. From a stock of female Ivanovas-Wistar rats with a history of regular 4-day vaginal cycles, 6-7 synchronous animals were allocated to one of the following groups: I, controls with solvent treatment; II, treatment groups: a) $0.1 \mathrm{mg} / \mathrm{kg}$ s.c. CB 154 , b) $0.3 \mathrm{mg} / \mathrm{kg}$ s.c, $\mathrm{CB} 154, \mathrm{c}) 1.0 \mathrm{mg} / \mathrm{kg}$ s.c. CB 154 .

Treatment was given at $17 \mathrm{~h}$ of postoestrus day and again on the next morning at $09.30 \mathrm{~h}$, the prooestrus day. Animals that showed a clear prooestrus smear were killed at $17.00 \mathrm{~h}$ of this same day by decapitation. The pituitaries were quickly removed, dissected, the anterior lobe weighed and deepfrozen until used for analysis.

For assessing the prolactin content of the pituitaries, the disc-electrophoresis procedure, as mentioned by YANAI and NAGASAWA ${ }^{3}$, was used. The prolactin bands

Prolactin content of rat adenohypophysis (mU/mg) at $17.00 \mathrm{~h}$ of prooestrus

\begin{tabular}{|c|c|c|c|c|}
\hline \multirow[b]{2}{*}{ CB 154 (mg/kg s.c.) } & \multirow{2}{*}{$\frac{\text { Controls }}{0}$} & \multicolumn{2}{|c|}{ Treatment groups } & \multirow[b]{2}{*}{1.0} \\
\hline & & 0.1 & 0.3 & \\
\hline & $\begin{array}{l}29.3 \\
25.2 \\
27.6 \\
25.8 \\
29.4 \\
28.9\end{array}$ & $\begin{array}{l}37.0 \\
35.1 \\
38.4 \\
38.3\end{array}$ & $\begin{array}{l}44.0 \\
43.2 \\
45.3 \\
46.0 \\
43.1\end{array}$ & $\begin{array}{l}53.5 \\
54.0 \\
55.1 \\
55.0 \\
52.0\end{array}$ \\
\hline $\mathrm{m}$ & 27.7 & 37.2 & 44.3 & 53.9 \\
\hline$\pm \mathrm{SD}$ & 1.8 & 1.5 & 1.3 & 1.3 \\
\hline$n$ & 6 & 4 & 5 & 5 \\
\hline$P$ & & $<0.001$ & $<0.001$ & $<0,001$ \\
\hline
\end{tabular}

were measured photodensitometrically and the results compared with those of a standard sheep prolactin preparation (Ferring) run in parallel at several concentrations.

The results are calculated in $\mathrm{mU} / \mathrm{mg}$ anterior pituitary, assuming the standard to contain $1000 \mathrm{IU}$ per ampoule.

Results and discussion. The results are presented in the Table. They show that pretreating 4-day cycling rats with CB 154 late in postoestrus and again in the morning of prooestrus produces a higher pituitary prolactin content on the afternoon of prooestrus than in untreated control animals. On the basis of observations by others ${ }^{1}$ on the prolactin depletion of rat pituitaries during the prooestrus phase, this effect of CB 154 is interpreted as demonstrating its inhibitory effect on pituitary prolactin release. These observations corroborate indirect evidence for the inhibitory effect of CB 154 on prolactin secretion in the rat, using other experimental situations ${ }^{4-6}$.

Résumé. Le traitement des femelles par le CB 154 a produit des taux de prolactine accrus, comparés à ceux des individus non traités. Cet effet dépendait de la dose de CB 154. Il a démontré que ce composé est également efficace en état de stimulation endogène de la prolactine.

\section{E. Kovacs and E. FiÜCKIGER}

Biological and Medical Research Division,

Sandoz Lid., CH-4002 Basel (Switzerland), 27 June 1974.

1 A. Yokojama, H. Tomogane and K. Ôta, Experientia 27, 578 (1971).

${ }^{2}$ G. D. Niswender, C. L. Chen, A. B. Midgley, J. Meites and S. Elluis, Proc. Soc. exp. Biol. Med. 130, 793 (1969).

3 R. Yanai and H. Nagasawa, Proc. Soc. exp. Biol. Med. 137, 167 (1969).

4 E. Flückiger, P. M. Lutterbeck, H. R. WAgner and E. BilleTER, Experientia 28, 924 (1972).

5 E. Billeter and E. Flúckiger, Experientia 27, 464 (1971),

6 E. Flückiger and H. R. WAGNeR, Experientia 24, 1130 (1968). 